DOI 10.15290/cnisk.2020.02.09.01

\author{
RAFAt KOSIŃSKI \\ https://orcid.org/0000-0003-1245-6729 \\ Uniwersytet w Białymstoku
}

\title{
Kilka uwag o specyfice badań nad historią kobiet w późnej starożytności i Bizancjum ${ }^{1}$
}

\begin{abstract}
Streszczenie
Niniejszy artykuł jest próbą ukazania najważniejszych trudności w badaniach prowadzonych nad historią kobiet w późnej starożytności i Bizancjum. Wskazuje najistotniejsze różnice w tego typu badaniach dotyczacych różnych epok historycznych. Największym problemem w badaniach kobiecych w epokach przed-nowożytnych jest charakter źródeł, których autorkami w niewielkim jedynie zakresie były kobiety, w dodatku przede wszystkim kobiety wywodzace się z elit. Zazwyczaj na świat kobiet w tych czasach patrzymy przez pryzmat autorów, którzy byli mężczyznami, najczęściej również pochodzacymi z elit. Dlatego aby badać dzieje kobiet w antyku i Bizancjum, trzeba przede wszystkim wykorzystywać metodologię charakterystyczną dla studiów klasycznych, umiejętnie łącząc ją z metodologią wypracowana dla zgłębiania historii kobiet.
\end{abstract}

Słowa kluczowe: dzieje kobiet w antyku; kobiety w Bizancjum; proweniencja źródeł antycznych

1 Publikacja przygotowana/finansowana w ramach programu Ministra Nauki i Szkolnictwa Wyższego pod nazwa DIALOG w latach 2019-2021. Jest wynikiem udziału w projekcie badawczym pt. „Ośrodek badań historii kobiet”, nr 0016/DLG/2019/10. 


\title{
A FEW COMMENTS ON THE SPECIFIC CHARACTER OF THE RESEARCH INTO THE HISTORY OF WOMEN IN LATE ANTIQUITY AND BYZANTIUM
}

\begin{abstract}
The present article aims to show the most important difficulties connected with the research on the history of women in Late Antiquity and Byzantium. It also points to the significant differences that exist in such studies as relating to various historical periods. The major problem occurring in the women's studies focused on pre-modern periods is the nature of the sources as represented by only a very limited number of female authors (most of whom would represent the elite circles of society). Most often, the world of women in that period is depicted from the perspective of male authors, usually members of the upper classes themselves. For this reason, the study of the history of women in Antiquity and in the Byzantine period should require the use of the methodology specific to classical studies with the reliance on the applicable methods elaborated for the purposes of women's studies.
\end{abstract}

Keywords: history of women in Antiquity; women in the Byzantine Empire; provenance of sources in Antiquity

Kompleksowa analiza badań nad historią kobiet w starożytności i Bizancjum jest przedsięwzięciem przekraczającym możliwości niniejszego szkicu i domaga się raczej osobnej monografii ${ }^{2}$. $Z$ tych też względów artykuł ten ogranicza się jedynie do zarysowania głównych aspektów

\footnotetext{
2 Zdaję sobie doskonale sprawę $z$ wieloznaczności terminu „studia kobiece” i wielości sporów metodologicznych dotyczących klasyfikacji tych studiów oraz wielu sporów w historiografii dotyczących tych pojęć. W niniejszym artykule pod pojęciem tym rozumiem badanie dziejów kobiet, ich sytuacji prawnej, rzeczywistości społecznej i kulturowej, jak również autoprezentacji i samoświadomości w okresie późnej starożytności i w Bizancjum. W kwestii sporów o właściwą nomenklaturę warto zapoznać się przede wszystkim $z$ bardzo inteligentnym i wartościowym (aczkolwiek dyskusyjnym) artykułem: Andrzej Kompa, „Kobieta rzymska, kobieta bizantyńska - co studia klasyczne moga zaoferować dzisiejszym gender studies?”, w: Bożena Czwojdrak, Agata A. Kluczek (red.), Kobieta i władza w czasach dawnych, (Katowice : Wydawnictwo Uniwersytetu Śląskiego, 2015), 49-68. Vide: Danuta Musiał, „Kobieta i mężczyzna w świecie antycznym: uwagi o starych sporach i nowych oczekiwaniach", Klio. Czasopismo poświęcone dziejom Polski i powszechnym, t. 26, 2013, 5-16.
} 
tych badań, przede wszystkim najważniejszych trudności w badaniach dotyczących kobiet w tych epokach, jednakże bez ich wyczerpującego omówienia.

W badaniach nad historia kobiet jedynie znikomy procent stanowią prace poświęcone epokom przednowożytnym, średniowieczu - zachodniemu czy też bizantyńskiemu - oraz starożytności, co doskonale widoczne jest zwłaszcza w polskich badaniach. Nie wynika to bynajmniej $z$ niechęci specjalizujących się w tych epokach historyków do tego typu badań, właściwej im metodologii czy jakiegoś konserwatyzmu badaczy, lecz z obiektywnych ograniczeń. Truizmem jest bowiem stwierdzenie, że badania historyczne są warunkowane zachowanymi źródłami, bez względu na to, czy sa to źródła pisane, czy też zabytki materialne. Historyk uzależniony jest bowiem od tego, co ludzie w danej epoce wytworzyli, a następne pokolenia zechciały zachować. Jesteśmy jednym słowem niemal całkowicie zdani na gust, modę czy sposób życia przeszłych pokoleń.

Jakie więc ograniczenia napotyka historyk starożytności czy też historyk Bizancjum w badaniach nad historią kobiet, które uniemożliwiaja zastosowanie metod wykorzystywanych dla badań dotyczacych XX i XXI w.? Podstawowym jest charakter źródeł, który dla żadnej z epok przednowoczesnych nie ma charakteru masowego. Nie posiadamy antycznych akt parafialnych czy innych analogicznych źródeł odnotowujących zmiany demograficzne (narodziny, śmierć, małżeństwa). Wyjątek w tym braku źródeł dokumentacyjnych stanowi co prawda późnoantyczny Egipt, gdzie warunki klimatyczne pozwoliły zachować się ogromnej liczbie dokumentów papirusowych, które w innych warunkach ulegają rozpadowi. Zbiór ten obejmuje między innymi umowy, testamenty, zapiski gospodarcze itd., jednak jest to w dużym stopniu zbiór nadal nieopracowany (w muzeach i archiwach znajduja się skrzynie pełne odkrytych papirusów, które nadal pozostaja niedostępne badaczom), fragmentaryczny (stan zachowania papirusów jest często na tyle zły, że w ogóle uniemożliwia ich odczytanie, natomiast wielu $z$ tych, które można częściowo odczytać, nie można datować albo określić precyzyjnie ich charakteru). Generalnie zbiory papirusowe są wielka przypadkową ${ }^{3}$.

3 Ogólnie o papirusach jako podstawowym materiale piśmienniczym vide: Roger S. Bagnall, Reading Papyri, Writing Ancient History, (London-New York : Routledge, 2019). Cf. także Benedetto Bravo, Ewa Wipszycka, „Wprowadzenie do źródłoznawstwa antycznego”, w: Ewa Wipszycka (red.), Vademecum historyka starożytnej Grecji i Rzymu, t. 1, (Warszawa : Państwowe Wydawnictwo Naukowe, 1982), 9-11. 
Problemem jest również to, że Egipt nie był typową, a wyjątkowa prowincją rzymska, zarówno pod względem społecznym, gospodarczym, jak i administracyjnym. Możemy więc badać różne aspekty społeczne późnorzymskiego Egiptu ${ }^{4}$, ale nie możemy wyników tych badań przełożyć na pozostałe regiony cesarstwa.

Kolejna przeszkoda w badaniach dotyczących kobiet w starożytności jest to, że przytłaczająca większość źródeł antycznych została wytworzona przez mężczyzn i to aż do czasów chrześcijańskich mężczyzn przede wszystkim związanych ze społecznymi elitami. Nie możemy zatem na ich podstawie przebadać samoświadomości kobiet, a jedynie obraz kobiety, jaki funkcjonował wśród męskich przedstawicieli elity społecznej, czyli w środowisku niewielkim, których horyzonty czy generalnie kultura znacznie odbiegały od świata przeciętnego mieszkańca basenu Morza Śródziemnego. Nie posiadamy kobiecych pamiętników, wspomnień, a nawet (poza nielicznymi wyjątkami) listów. Jeżeli więc źródła sa tworzone przez mężczyzn i odzwierciedlaja męski punkt widzenia, bardzo często operuja one stereotypami i pewnymi toposami dotyczacymi kobiet. Nawet gdy wraz z chrześcijaństwem krag osób tworzących literaturę wyszedł poza elitę społeczna, a za pióro chwycili mężczyźni z niższych warstw społecznych, duchowni czy mnisi, to również oni, zdobywając swe umiejętności literackie, przejmowali istniejące stereotypy ${ }^{5}$. Zreszta owe stereotypy nie istniały jedynie na papirusie, ale były odzwierciedleniem schematów myślenia i postrzegania rzeczywistości istniejacych w społeczeństwie. Sa więc doskonałym źródłem do badań mentalności, ale mentalności mężczyzn, nie kobiet.

Powyższe uwagi nie oznaczają oczywiście, że kobiety niczegonie pozostawiły po sobie w źródłach pisanych $z$ epoki antycznej czy

\footnotetext{
4 Cf. chociażby Roger S. Bagnall, Bruce W. Frier, The Demography of Roman Egypt, (Cambridge : Cambridge University Press, 1994).

5 O zasięgu znajomości pisma w antyku vide: Ewa Wipszycka, „Z problematyki badań nad zasięgiem znajomości pisma w starożytności", Przeglad Historyczny, t. 74, 1983, 1-27 oraz William V. Harris, Ancient Literacy, (Cambridge, Mass.-London : Harvard University Press, 1989). O znajomości pisma w epoce bizantyńskiej vide: Robert Browning, „Literacy in the Byzantine World”, Byzantine and Modern Greek Studies, t. 4, 1978, 39-54 oraz Évelyne Patlagean, "Discours écrit, discours parlé. Niveaux de culture à Byzance aux VII $-\mathrm{XI}^{\mathrm{e}}$ siècles", Annales ESC, t. 34, 1979, 264-278. Należy jednak podkreślić, że dotychczas nie opracowano pełnej i kompleksowej analizy poziomu piśmiennictwa w Bizancjum, cf. Catherine Holmes, Judith Waring, "Preface", w: eaedem (red.), Literacy, Education and Manuscript Transmission in Byzantium and Beyond, (Leiden- Boston-Cologne : Brill, 2002), vii.
} 
bizantyńskiej ${ }^{6}$, jednak przywilej tworzenia literatury czy pisania listów należał do przedstawicielek sfer wyższych, kobiet $z$ arystokracji czy domu panującego. Oczywiście również od tej zasady istnieja pewne wyjątki, które dotyczą chociażby późnoantycznych wyznawczyń neoplatonizmu, jednak dzieła Sozypatry czy znacznie słynniejszej Hypatii z Aleksandrii $\mathrm{w}$ ogóle nie zachowały się do naszych czasów ${ }^{7}$. Co zatem $z$ twórczości kobiet tego okresu pozostało? Wydaje się, że bizantyńscy skrybowie (lub raczej ci, którzy zlecali im przepisanie konkretnych utworów) mieli pewien sentyment do chrześcijańskiej twórczości przedstawicielek domu cesarskiego epoki postkonstantyńskiej. Przykładowo żona cesarza Teodozjusza II, Eudokia (przed chrztem noszaca imię Atenais), która tworzyła poezje pisana heksametrem, pozostawiła po sobie dość obszerny zbiór - zachowało się 900 wersów z jej Męczeństwa świętego Cypriana, napisanego w trzech księgach, jak również pokaźny zbiór aż 2,344 wersów jej homerocentonów ${ }^{8}$. O tym, jak znaczny jest to zbiór, świadczy chociażby proste porównanie do zasobu zachowanych utworów słynnych poetek greckich epoki klasycznej czy hellenistycznej: przykładowo $z$ twórczości Telesilly (VI w. p.n.e.) przetrwało zaledwie kilka wersów ${ }^{9}$, Korynny z Tanagry (2. poł. VI w. p.n.e.) 110 wersów $^{10}$; Nossis (IV/III w. p.n.e.)

6 Oczywiście wszelkie pozostałości kobiecej literatury antyku są skrupulatnie badane, o czym świadczy chociażby praca: Andre Lardinois, Laura McClure (red.), Making Silence Speak. Women's Voices in Greek Literature and Society, (Princeton : Princeton University Press, 2018).

7 O Sozypatrze vide: Ilinca Tanaseanu-Döbler, "Sosipatra - Role Models for "Divine" Women in Late Antiquity", w: Maria Dzielska, Kamilla Twardowska (red.), Divine Men and Women in the History and Society of Late Hellenism, (Kraków : Wydawnictwo Uniwersytetu Jagiellońskiego, 2013), 123-147; o Hypatii przede wszystkim Maria Dzielska, Hypatia $z$ Aleksandrii, (Kraków : Universitas, 2006).

8 Poza tym zachowało się również 16 wersów jej autorstwa w inskrypcji w Hamat Gader, vide: Kazimierz Ilski, „Eudokia Athenais - eine Dichterin in der Welt der Politik“, w: Motivi e forme della poesia cristiana antica tra scrittura e tradizione classica. XXXVI Incontro di studiosi dell'antichità cristiana, Roma, 3-5 maggio 2007, (Roma : Institutum patristicum Augustinianum, 2008), 443-451; Kamilla Twardowska, "Religious Foundations of Empress Athenais Eudocia in Palestine", w: Kamilla Twardowska, Maciej Salamon, Sławomir Sprawski, Michał Stachura, Stanisław Turlej (red.), Within the Circle of Ancient Ideas and Virtues. Studies in Honour of Professor Maria Dzielska, (Kraków : Towarzystwo Wydawnicze „Historia Iagellonica”, 2014), 307-317 oraz Małgorzata B. Leszka, Mirosław J. Leszka, Bazylisa. Świat bizantyńskich cesarzowych IV-XV wiek, (Łódź : Wydawnictwo Uniwersytetu Łódzkiego, 2017), 166-175.

9 O Telesilli vide: Emmet Robbins, „Telesilla“, w: Der Neue Pauly, t. 12/1, (Stuttgart : Metzler Verlag, 2002), 96.

10 O Korynnie vide: Lidia Winniczuk, Twórczość poetek greckich, (Warszawa : Państwowe Wydawnictwo Naukowe, 1956), 67-91; Iza Bieżuńska-Małowist, Kobiety antyku. Talenty, 
12 epigramów ${ }^{11}$, zaś Anyte $z$ Tegei (III w. p.n.e.) 24 epigramy ${ }^{12}$. Natomiast zachowaniu się licznych pozostałości z twórczości Eudokii nie przeszkadzał bynajmniej nawet fakt, że jej talent i poziom twórczości nie sa oceniane zbyt wysoko. Niestety ilość poezji Eudokii niewiele mówi ani o niej samej, ani o jej postrzeganiu rzeczywistości, gdyż w swej, głównie religijnej, twórczości dostosowywała się ona do utartych kanonów literackich, których twórcami byli mężczyźni. W każdym razie spora liczba informacji o kobietach $z$ rodzin cesarskich, począwszy od późnej starożytności do końca istnienia Bizancjum, zachęca badaczy do przygotowania coraz to nowych publikacji, również w języku polskim, poświęconych cesarzowym $\mathrm{i}$ innym kobietom związanym $\mathrm{z}$ rodzina cesarska ${ }^{13}$.

ambicje, namiętności, (Warszawa : Wydawnictwo Naukowe PWN, 1993), 249-250 oraz Daniel W. Berman, „The Language and Landscape of Korinna”, Greek, Roman, and Byzantine Studies, vol. 50, 2010, 41-62.

11 O Nonnis vide: Sylvia Barnard, "Hellenistic Women Poets", The Classical Journal, t. 73.3, 1978, 210; Anna Świderkówna (red.), Słownik pisarzy antycznych, (Warszawa : Wydawnictwo Wiedza Powszechna, 2001), 356 oraz Laurel Bowman, "The 'Women's Tradition' in Greek Poetry”, Phoenix, t. 58 (1), 2004, 16.

12 O Anyte vide: Kathryn J. Gutzwiller, "Anyte's Epigram Book", Syllecta Classica, t. 4, 1993, 71-89. Oczywiście wyjątkiem jest tu słynna Safona, z której twórczości zachowało się około 550 wierszy (na około 10 tysięcy, jakie miała napisać), vide: Jim Powell, The Poetry of Sappho, (Oxford : Oxford University Press, 2007). Szerzej o poetkach greckich vide: Yves Battistini, Poétesses grecques. Sapphô, Corinne, Anytè..., (Paris : Imprimerie Nationale, 1998).

${ }^{13}$ W języku polskim ukazały się badania Kamilli Twardowskiej, Cesarzowe bizantyjskie 2 poł. V w. Kobiety a władza, (Kraków : Towarzystwo Wydawnicze „Historia Iagellonica”, 2006) oraz wspomniana wyżej praca małżeństwa Leszków. Podobnych prac w obiegu międzynarodowym jest oczywiście znacznie więcej, vide chociażby Kenneth G. Holum, Theodosian Empresses. Women and Imperial Dominion in Late Antiquity, (Berkeley-Los Angeles : University of California Press, 1982); Liz James, Empresses and Power in Early Byzantium, (London-New York : Leicester University Press, 2001); Barbara Hill, Imperial Women in Byzantium 1025-1204. Power, Patronage and Ideology, (New York : Routledge, 1999); Lynda Garland, Byzantine Empresses: Women and Power in Byzantium, AD 527 1204, (London-New York : Routledge, 1999) czy Judith Herrin, Women in Purple: Rulers of Medieval Byzantium, (London : Phoenix Press, 2002); książka w polskim przekładzie wydanym w wydawnictwie Bellona zyskała bardzo poetycki, aczkolwiek nieadekwatny, tytuł: Krwawe cesarzowe. Nawet poszczególne cesarzowe doczekały się swych biografii, jak np. cesarzowa Pulcheria [Christine Angelidi, Pulcheria. La Castita al Potere, (Milano : Jaca Book, 1998)] czy Teodora [Paolo Cesaretti, Teodora, tłum. Bogumiła Bielańska, (Warszawa : Świat Ksiązki, 2003)]. Również jedyne dzieło bizantyńskiej historiografii, które wyszło spod ręki kobiety, to Aleksjada Anny Komneny, roztaczające panoramę dziejów Bizancjum za panowania jej ojca, cesarza Aleksego Komnena. Mimo że dzieło to stanowi zasadniczo panegiryk ku czci ojca napisany klasycznym językiem, jest podstawą licznych badań nad osobą autorki. $Z$ najnowszych monografii vide: Leonora Neville, Anna Komnene: the life and work of a medieval historian, (New York : Oxford University Press, 2016) oraz prace zbiorowa Thalia Gouma-Peterson (red.), Anna Komnene and Her Times, (New 
Jak więc widać, stan zachowania twórczości kobiecej w dawnych epokach rośnie gwałtownie wraz z rozpowszechnieniem się chrześcijaństwa. $Z$ czego to wynika? Czy chrześcijanie masowo niszczyli wcześniejsze utwory pogańskie, w tym utwory kobiece? Nie. Należy pamiętać, że podstawowym materiałem piśmienniczym w antyku był papirus, który w normalnych warunkach (o wyjatku, jaki stanowi Egipt, już wspomnieliśmy) potrafi przetrwać stosunkowo krótki okres, a następnie, jako produkt roślinny, zazwyczaj się rozpada ${ }^{14}$. Jeżeli w odpowiednim czasie nikt treści papirusu nie przepisze, zazwyczaj bezpowrotnie ona zginie. Większość zachowanych rękopisów literatury antycznej pochodzi dopiero $z$ drugiego tysiąclecia, kiedy to ich nośnikiem był już nie papirus, ale dużo trwalszy pergamin, a następnie papier. Nikt więc nie musiał celowo niszczyć czy palić antycznej literatury, wystarczyło, że dany utwór nie pasował do gustu lub potrzeb czytelników/słuchaczy, aby zaginął. Materiał piśmienniczy był dość drogi, podobnie jak koszt pracy skryby. Powielano zatem jedynie te dzieła, które na to (oczywiście w ocenie decydujących o tym osób - najczęściej przedstawicieli elit, a następnie czołowych duchownych chrześcijańskich czy zwierzchników klasztorów) zasługiwały. Biorąc to pod uwagę, zaskakiwać nawet może znaczna liczba pogańskich utworów czy dzieł wręcz jawnie antychrześcijańskich wytrwale przepisywanych przez kolejne pokolenia mnichów. Współczesne wyobrażenie o fanatycznych zakonnikach wyszukujących i palacych wszystko, co wydawało im się błędne czy szkodliwe, jest zwykłym anachronizmem. W każdym razie niemal wszystko, co zachowało się $z$ antyku (podobnie jak przeważająca część źródeł bizantyńskich), musiało w pewnym okresie zostać przepisane przez chrześcijańskich skrybów.

Zjawisko to może wyjaśniać, dlaczego niechrześcijańskie piśmiennictwo kobiece nie było przepisywane przez mnichów równie gorliwie, co pogańskie traktaty wymierzone w nową religię - najczęściej nie trafiały one $\mathrm{w}$ ich gusta czy zainteresowania. Natomiast wraz $z$ chrystianizacją elit cesarstwa rzymskiego, o czym już wspomnieliśmy, gwałtownie rośnie liczba zachowanych utworów kobiecych, w dużym stopniu mających charakter religijny. Niestety, nawet ta rewolucyjna zmiana nie

York : Garland Publishing, Inc., 2000) - zwłaszcza ta ostatnia praca wpisuje się w nurt badań kobiecych).

14 Ogólnie o książce papirusowej: David Diringer, The Book before Printing: Ancient, Medieval and Oriental, (New York : Dover Publications, 1982), 113-168. 
pomaga zbytnio w badaniach dotyczących kobiet późnego antyku czy Bizancjum, gdyż nadal gros tych zachowanych utworów zostało stworzone przez przedstawicielki elit. Również wzrost popularności ruchów ascetycznych u schyłku starożytności nie oznaczał „demokratyzacji” kobiecej literatury. O ile bowiem wielu spośród piszących mnichów wywodziło się $z$ niższych warstw społecznych, to wśród mniszek te chwytające za pióra pochodziły przeważnie $z$ elit ${ }^{15}$. Biorąc to wszystko pod uwage, nie dziwi fakt, że nie istnieje żadne międzynarodowe czasopismo zajmujące się historia kobiet w Bizancjum ${ }^{16}$.

Wraz $z$ rozwojem chrześcijaństwa, w którym status kobiety był wyższy niż w tradycyjnym społeczeństwie grecko-rzymskim, pojawiać zaczęła się ogromna liczba utworów skierowanych do kobiet lub takich, których kobiety były bohaterkami ${ }^{17}$. Do tej pierwszej grupy należą różnego rodzaju pouczenia, traktaty zachęcające do podjęcia ascezy lub pisma instruujące niewiasty, które już życie ascetyczne podjęły. Dysponujemy też, począwszy od przełomu IV i V w., spora liczbą listów, których adresatkami były kobiety. Przykładowo Hieronim ze Strydonu korespondował $z$ wieloma przedstawicielkami arystokracji rzymskiej ${ }^{18}$. Zainteresowanie

${ }_{15} \mathrm{~W}$ przypadku mnichów zachowało się bardzo dużo utworów, których autorami byli przedstawiciele niższych warstw społecznych. Wynika to głównie (choć nie tylko) z tego, że mnisi, aby móc korzystać z Biblii, zazwyczaj musieli opanować sztukę czytania (niekoniecznie pisania), jakkolwiek należy pamiętać, że część mnichów nie miała bezpośredniego dostępu do kodeksów czy zwojów, a byli oni odbiorcami słowa pisanego głównie jako słuchacze.

${ }^{16}$ Wydaje się, że taki cel w jakimś stopniu miało spełniać czasopismo Basilissa, wydawane przez Institute of Byzantine Studies at Queen's University Belfast, którego pierwszy numer, liczaccy 143 strony, wyszedł w 2004 r. Niestety, po 2004 r. przestał się ukazywać, chociaż przygotowywany był kolejny tom. Nie oznacza to, że liczba prac dotyczących historii kobiet w Bizancjum jest niewielka, o czym świadczyć może chociażby niemała liczba pozycji w internetowej Bibliography on Gender in Byzantium tworzonej w Dumbarton Oaks - https://www.zotero.org/groups/2282665/dumbarton_oaks_bibliography_on_gender_ in_byzantium/items/QAKMC4I3/library (dostęp: 27.05.2020).

17 Ogólne refleksje o roli kobiet w Kościele pierwotnym: Ewa Wipszycka, Kościót w świecie późnego antyku, (Warszawa : Państwowy Instytut Wydawniczy, 1994), 281-299.

${ }_{18}$ W zbiorze 156 listów Hieronima blisko trzecia ich część skierowana była do różnych przedstawicielek rzymskiej arystokracji lub ascetek. Ich adresatkami były dziewice emoneńskie (list 11), Kastoryna (list 13), Eustochium (list 22, 31, 46, 108), Marcela (list 23-29, 32, 34, 37-38, 40-44, 46, 59, 72), Paula (list 30, 33, 39, 46), Asela (list 45), Furia (list 54), Fabiola (list 64, 78), Pryncypia (list 65, 127), Teodora (list 75), Salwina (list 79), Leta (list 107), nieznane bliżej matka i córka z Galii (list 117), Hedybia (list 120), Algazja (list 121), Geruchia (list 123), Anapsychia (list 166), Demedriada (list 130), Celancja (list 148), cf. Hieronim ze Strydonu, Listy, t. 1-5, oprac. na podstawie tłumaczenia ks. Jana Czuja Monika Ożóg, tekst łaciński Henryk Pietras, (Kraków : Wydawnictwo WAM, 2010-2013). Osobno w przekładzie na język polski opublikowano zbiór listów Hieronima 
tymi niewiastami (jak również ich pieniędzmi) umożliwiło ustawodawstwo cesarzy chrześcijańskich, które dało sposobność wyemancypowania się kobiet spod kurateli mężczyzn zarządzających dotąd majątkami wdów lub możliwość ucieczki przed przymusowym małżeństwem w przypadku podjęcia życia ascetycznego ${ }^{19}$. Wspomniany powyżej Hieronim stał na czele klasztoru w Betlejem, którego utrzymanie zapewniało mu stałe wsparcie finansowe rzymskiej arystokratki Pauli. $Z$ kolei pochodzaca $z$ arystokracji senatorskiej bogata wdowa Olimpia po śmierci swego męża Nebridiosa, nie mając jeszcze ukończonego dwudziestego roku życia, musiała stoczyć $z$ pomoca konstantynopolitańskiego biskupa prawdziwa batalię $z$ cesarzem Teodozjuszem I, aby mogła podjąć życie ascetyczne, zachowując tym samym kontrolę nad swoim majątkiem ${ }^{20}$.

Niestety również w przypadku wspomnianej wyżej bogatej epistolografii napotykamy znane już dwojakie ograniczenia. Po pierwsze autorami listów sa przeważnie mężczyźni (to listy Hieronima do kobiet były zbierane i przepisywane, a nie jego korespondentek), po drugie adresatkami tych listów były przeważnie kobiety $z$ elit. Dlatego też możemy badać życie niewiast $z$ arystokracji senatorskiej czy zwłaszcza domu cesarskiego, zaś życie kobiet $z$ niższych warstw społecznych jest przez tę korespondencję ukazywane w niewielkim stopniu ${ }^{21}$.

Nie jesteśmy jednak w epoce późnoantycznej i bizantyńskiej na zupełnie straconej pozycji. Pewne aspekty życia społecznego, w tym oczywiście także te, które związane były z kobietami, są naświetlone przez

do Eustochium: św. Hieronim, Listy do Eustochium, tłum., wstęp i oprac. Bazyli Degórski, (Kraków : Wydawnictwo Tyniec, 2004). Również w zbiorze listów Jana Chryzostoma znajduje się wiele listów skierowanych do niewiast, w tym do konstantynopolitańskiej diakonisy Olimpii, która biskup wysoko cenił. Listy do niej zostały zebrane i opublikowane w: Jean Chrysostome, Lettres à Olimpias, seconde édition augmentée de la Vie anonyme d'Olimpia, introduction, texte critique, traduction et notes par Anne-Marie Malingrey, (Paris : Les Éditions du CERF, 1968). Olimpia korespondowała również z innymi wybitnymi teologami, Grzegorzem z Nazjanzu, Piotrem z Sebasty czy Amfilochem z Ikonium.

$19 \mathrm{~W}$ prawie rzymskim epoki cesarstwa przysługiwało wprawdzie teoretycznie matkom, które urodziły trójkę dzieci, prawo samodzielnego zarządzania swymi finansami (ius trium liberorum), jednak dopiero chrystianizacja cesarstwa umożliwiła to młodym wdowom, dając im prawo do pozostania w stanie bezżennym $z$ pełną władzą nad swym majątkiem.

${ }_{20}$ Obszerny biogram Olimpii w: Heike Grieser, Olympias, w: Reallexikon für Antike und Christentum, t. 26, (Stuttgart : Anton Hiersemann Verlag, 2015), 125-131.

${ }_{21}$ Zachowane listy, których autorkami były kobiety $z$ rodziny cesarskiej, mają najczęściej charakter formalny, jak chociażby listy augusty Pulcherii czy augusty Eudocji, vide: Julia Hillner, "Empresses, Queens, and Letters: Finding a 'Female Voice' in Late Antiquity?", Gender \& History, t. 31.2, 2019, 353-382. 
dwa typy źródeł. Pierwszym $z$ nich sa szeroko rozumiane zabytki prawa, zarówno cesarskiego, jak i kościelnego. Z V i VI w. pochodzą dwa słynne kodeksy prawa rzymskiego - Teodozjański z 438 r. i Justyniański z 534 r. - wraz z licznymi uzupełnieniami, nowelami czy komentarzami ${ }^{22} . Z$ kolei akta synodalne przedstawiaja rozwiazania licznych kwestii moralnych czy też dyscyplinarnych związanych $\mathrm{z}$ funkcjonowaniem kobiet w Koście$1 \mathrm{e}^{23}$. W obu przypadkach oczywiście znów autorami dyspozycji prawnych są mężczyźni ${ }^{24}$.

Pozostaje nam jeszcze jeden gatunek literacki, który powstał w późnym antyku i zyskał niezwykła popularność w Bizancjum (o czym świadczy zarówno liczba znanych utworów, jak i ich zachowanych kopii). Mowa o hagiografii. Hagiografia stała się dla nas często jedyną droga, która pozwala badaczowi w jakimś stopniu wniknąć w świat niższych grup społecznych, ludzi wykluczonych, niemających literackiego głosu. Dotyczy to nie tylko drobnych kupców, rzemieślników czy chłopów, ale także niewolników czy grup przestępczych. Na kartach dzieł hagiograficznych odmalowany został cały wachlarz rzeczywistości społecznej, która pozostaje poza zainteresowaniem „wysokiej” literatury, kronik, historiografii czy wspomnianej wyżej epistolografii ${ }^{25}$. Ponieważ na kartach dzieł hagiograficznych pojawiają się często kobiety, w dodatku pochodzące głównie

\footnotetext{
${ }^{22}$ Ogólnie o prawodawstwie postklasycznym vide: Adriaan J. Boudewijn Sirks, "From the Theodosian to the Justinian Code", w: Atti dell' Accademia Romanistica Costantiniana: VI Convegno Internazionale, (Perugia : Libreria universitaria, 1986), 265-302; Jill Harries, Law and Empire in Late Antiquity, (Cambridge : Cambridge University Press, 1999) oraz Ewa Wipszycka, „Źródła normatywne świeckie”, w: eadem (red.), Vademecum historyka starożytnej Grecji i Rzymu, t. 3, Źródłoznawstwo czasów późnego antyku, (Warszawa : Wydawnictwo Naukowe PWN, 1999), 585-617.

23 Odnośnie do akt synodalnych vide przede wszystkim monumentalne wielotomowe studium Karl J. Hefele, Henri Leclercq, Histoire des conciles d'après les documents originaux, (Paris : Letouzey et Ané, Éditeurs, 1907-1952). Dysponujemy także wydaniem tekstów oryginalnych akt synodalnych wraz z polskim przekładem, doprowadzonym do roku 600: Arkadiusz Baron, Henryk Pietras (red.), Synody i Kolekcje Praw, t. 1, Acta Synodalia ann. 50-381, (Kraków : Wydawnictwo WAM, 2006); t. 4, Acta Synodalia ab anno 381 ad annum 431, (Kraków : Wydawnictwo WAM, 2010); t. 6, Acta Synodalia ab anno 431 ad annum 504, (Kraków : Wydawnictwo WAM, 2011); t. 8, Acta Synodalia ab anno 506 ad annum 553, (Kraków : Wydawnictwo WAM, 2014); t. 12, Acta Synodalia ab anno 553 ad annum 600, (Kraków : Wydawnictwo WAM, 2020).

${ }_{24}$ Cf. dwutomowe dzieło Joëlle Beaucamp, Le statut de la femme à Byzance (4 $4^{e} 7^{e}$ siècle), (Paris : De Boccard, 1990-1992), która w pierwszym tomie analizuje prawny status kobiet, w drugim zaś rzeczywistość społeczną.

25 O hagiografii vide przede wszystkim Ewa Wipszycka, Robert Wiśniewski, „Hagiografia późnoantyczna”, w: Ewa Wipszycka (red.), Vademecum historyka starożytnej Grecji i Rzy$m u$, t. 3, 221-333.
} 
z niższych warstw społecznych, dzieła te sa brane pod uwage w szerokim wachlarzu prac społecznych czy ekonomicznych ${ }^{26}$. Hagiografia „kobieca” badana jest także po prostu jako źródło wiedzy o życiu i praktykach niewiast uznanych za święte ${ }^{27}$. Jednakże próby odtworzenia realiów świętych kobiet na podstawie żywotów rodza pewne niebezpieczeństwo. Przykładowo na podstawie kilku zachowanych żywotów pustelniczek nie można próbować odtwarzać ich świata, gdyż ich bohaterki prawdopodobnie nigdy nie istniały, a dzieła te były pomyślane jako utwory budujące i pouczające, nie zaś jako „biografie” autentycznych świętych ${ }^{28}$. Najsłynniejszym przykładem pustelnicy we wczesnym okresie monastycyzmu jest prawdopodobnie Maria Egipcjanka, która według jej Żywota miała wieść życie prostytutki w Aleksandrii, a następnie Jerozolimie, po czym nawróciła się i resztę swego życia spędziła, pokutując na pustyni za Jordanem. Jednakże Żywot Marii, który wyszedł być może spod pióra jerozolimskiego patriarchy Sofroniusza, jest jedynie literacką fikcją ${ }^{29}$.

W dużo większym stopniu można wykorzystać te dzieła hagiograficzne, w których kobiety i realia ich życia pojawiają się mimowolnie i nie stanowia głównego tematu utworu, a jedynie tło, na którym postaci pierwszoplanowe odgrywają swe role. I tak z Żywota Symeona Salosa dowiadujemy się, że ów święty głupiec z Emezy został oskarżony o utrzymywanie intymnych stosunków $z$ pewna prostytutką. Rychło jednak miało się okazać, że Symeon przynosił jej jedzenie, chleb i wino, gdyż $z$ braku środków do życia przez trzy dni głodowała. Dzięki temu opisowi mającemu świadczyć o cnotach świętego mimowolnie dowiadujemy się

${ }^{26}$ Przykładowo monumentalne dzieło Évelyne Patlagean, Pauvreté économique et pauvreté sociale à Byzance: $4^{e}-7^{e}$ siècles, (Paris : Mouton, 1977) oparte zostało w dużym stopniu właśnie na danych zaczerpniętych $z$ dzieł hagiograficznych.

27 Cf. chociażby wybory żywotów świętych kobiet: Alice-Mary Talbot (ed.), Holy Women of Byzantium. Ten Saints 'Lives in English Translation, (Washington D.C. : Dumbarton Oaks Research Library and Collection, 1996) czy Sebastian P. Brock, Susan A. Harvey (red.), Holy Women of the Syrian Orient, (Berkeley-Los Angeles-London : University of California Press, 1998).

${ }^{28}$ Cf. Ewa Wipszycka, Drugi dar Nilu czyli o mnichach i klasztorach $w$ późnoantycznym Egipcie, (Kraków : Wydawnictwo Tyniec, 2014), 298-304.

${ }_{29}$ Żywot Marii znany jest $z$ trzech wersji: krótkiej opowieści o psalmistce Marii zawartej w Żywocie Cyriaka autorstwa Cyryla ze Scytopolis z połowy VI w. (18-19), późniejszej anegdocie o bezimiennej mniszce zamieszczonej w Łace duchowej Jana Moschosa $z$ początku VII w. (179) i w końcu w Żywocie Marii pióra współczesnego Moschosowi Sofroniusza, cf. Maria Kouli, "Life of St. Mary of Egypt", w: Alice-Mary Talbot (red.), Holy Women of Byzantium, 65-93. A zatem plastyczny tytuł ksiażki Benedicty Ward poświęconej kobiecej ascezie pióra - Harlots of the Desert (Nierzadnice pustyni) - jest nie do konca adekwatny. 
o realiach życia prostytuujących się kobiet, niebędących ekskluzywnymi kurtyzanami $^{30}$. Z kolei w Żywocie Teodora $z$ Sykeon spotykamy Marię, która wraz ze swą matką i siostra prowadziła stację położona na trasie cursus publicus. Wszystkie trzy trudniły się poza tym prostytucją. Teodor, bohater dzieła i przyszły biskup Anastazjopolis, miał być synem Marii z przygodnego związu z posłańcem cesarskim, niejakim Kosmasem ${ }^{31}$. Żywoty dostarczają także wielu informacji o codziennym funkcjonowaniu takiego zajazdu na trasie cursus publicus ${ }^{32}$.

Należy wszakże pamiętać, że hagiografia jest bardzo specyficznym gatunkiem literackim, mającym określone cele i posługującym się wieloma schematami, wykorzystanie jej do badań wymaga poznania wypracowanych przez historiografię w ostatnim stuleciu metod badawczych, które pozwalają nam wniknąć pod warstwę powtarzalnych schematów i odczytywać oczyszczoną $z$ nich rzeczywistość społeczna ${ }^{33}$. Mimo że wiele żywotów opisuje życie świętych niewiast, pustelniczek, dziewic czy diakonis, to wszystkie zostały napisane przez mężczyzn, nie można ich więc traktować w żadnym wypadku jako formy autoprezentacji kobiet. Nawet one są nadal odbiciem męskich wyobrażeń o kobietach.

Podsumowując, należy podkreślić, że studia kobiece w późnej starożytności i Bizancjum napotykaja na szereg trudności $z$ uwagi na charakter i stan zachowania źródeł. Nie można zatem w sposób prosty zastosować metodologii wypracowanej dla tego typu badań dotyczących czasów nowożytnych, lecz należy łączyć ją z metodologią właściwą dla hermeneutyki źródła pisanego wypracowaną dla studiów klasycznych. Owoce tych badań nigdy wprawdzie nie będa porównywalne (ani ilościowo, ani jakościowo) $z$ badaniami prowadzonymi $z$ wykorzystaniem źródeł pochodzacych $z$ XX czy XXI w., nie znaczy to jednak, że studia takie nie sa prowadzone - sa, a w przyszłości zapewne będą rozwijane ${ }^{34}$.

\footnotetext{
30 Ewagriusz, Historia Kościoła, IV, 34. Epizod ten nie jest obecny w późniejszym Żywocie Symeona, który wyszedł spod pióra Leoncjusza $z$ Neapolis.

31 Jerzy, Vita Theodori Syceotae, 3.

32 Ibidem, 6.

${ }_{33}$ Takie badania prowadziła wspomniana wyżej Évelyne Patlagean, jak również już pół wieku wcześniej Aleksander Rudakow w swej, rewolucyjnej jak na tamte czasy, monografii Очерки византийской культуры по данным греческой агиографии, (Moskwa : b.m.w., 1917).

${ }^{34}$ Cf. np. Liz James, Women, men and eunuchs: gender in Byzantium, (London-New York : Routledge, 1997) czy eadem, "The Role of Women", w: Elizabeth Jeffreys, John Haldon, Robin Cormack (red.), The Oxford Handbook of Byzantine Studies, (Oxford : Oxford University Press, 2008), 643-651.
} 


\section{Bibliografia}

\section{Źródła}

Acta Synodalia - Baron, Arkadiusz. Pietras, Henryk (red.), Synody i Kolekcje Praw, t. 1, Acta Synodalia ann. 50-381, (Kraków : Wydawnictwo WAM, 2006); t. 4, Acta Synodalia ab anno 381 ad annum 431, (Kraków : Wydawnictwo WAM, 2010); t. 6, Acta Synodalia ab anno 431 ad annum 504, (Kraków: Wydawnictwo WAM, 2011); t. 8, Acta Synodalia ab anno 506 ad annum 553, (Kraków: Wydawnictwo WAM, 2014); t. 12, Acta Synodalia ab anno 553 ad annum 600, (Kraków: Wydawnictwo WAM, 2020). Cyryl ze Scytopolis, Żywot Cyriaka - Schwartz, Eduard (wyd.), Kyrillos von Skythopolis, (Leipzig : J. C. Hinrichs Verlag, 1939), 222-235.

Ewagriusz, Historia Kościoła-Bidez, Joseph. Parmentier, Léon (wyd.), The Ecclesiastical History of Evagrius with the scholia, (London : Methuen \& co., 1898).

Hieronim, Listy - Ożóg, Monika. Pietras, Henryk (red.), Hieronim ze Strydonu, Listy, t. 1-5, (Kraków : Wydawnictwo WAM, 2010-2013); Degórski, Bazyli (wyd.). św. Hieronim, Listy do Eustochium, (Kraków : Wydawnictwo Tyniec, 2004).

Jan Chryzostom, Listy do Olimpii- Malingrey, Anne-Marie (wyd.), Jean Chrysostome, Lettres à Olimpias, seconde édition augmentée de la Vie anonyme d'Olimpia, (Paris : Les Éditions du CERF, 1968).

Jan Moschos, Łakka duchowa - Rouët de Journel, Marie-Joseph (wyd.), Jean Moschus, Le Pré spirituel, (Paris : Les Éditions du CERF, 1946).

Jerzy, Vita Theodori Syceotae - Festugière, André-Jean (wyd.), Vie de Théodore de Sykéôn, t. 1-2, (Bruxelles : Société des Bollandistes, 1970).

Sofroniusz, Żywot Marii - Patrologia Graeca, t. 87, 3697-3725.

\section{Opracowania}

Angelidi, Christine. Pulcheria. La Castita al Potere, (Milano : Jaca Book, 1998).

Bagnall, Roger S. Reading Papyri, Writing Ancient History, (London-New York : Routledge, 2019).

Bagnall, Roger S. Frier Bruce W. The Demography of Roman Egypt, (Cambridge : Cambridge University Press, 1994). 
Barnard, Sylvia. "Hellenistic Women Poets", The Classical Journal, t. 73.3, 1978, 210.

Battistini, Yves. Poétesses grecques. Sapphô, Corinne, Anytè..., (Paris : Imprimerie Nationale, 1998).

Beaucamp, Joëlle. Le statut de la femme à Byzance ( $4^{e}-7^{e}$ siècle), (Paris : De Boccard, 1990-1992).

Berman, Daniel W. "The Language and Landscape of Korinna", Greek, Roman, and Byzantine Studies, t. 50, 2010, 41-62.

Bieżuńska-Małowist, Iza. Kobiety antyku. Talenty, ambicje, namiętności, (Warszawa: Wydawnictwo Naukowe PWN, 1993).

Boudewijn Sirks, Adriaan J. "From the Theodosian to the Justinian Code", w: Atti dell' Accademia Romanistica Costantiniana: VI Convegno Internazionale, (Perugia : Libreria Universitaria, 1986), 265-302.

Bowman, Laurel. “The 'Women's Tradition' in Greek Poetry”, Phoenix, t. 58.1, 2004, 16.

Bravo, Benedetto. Wipszycka, Ewa. Wprowadzenie do źródloznawstwa antycznego, w: Ewa Wipszycka (red.), Vademecum historyka starożytnej Grecji i Rzymu, t. 1, (Warszawa: Państwowe Wydawnictwo Naukowe, 1982), 9-11.

Brock, Sebastian P. Harvey, Susan A. (red.), Holy Women of the Syrian Orient, (Berkeley-Los Angeles-London : University of California Press, 1998).

Browning, Robert. „Literacy in the Byzantine World”, Byzantine and Modern Greek Studies, t. 4, 1978, 39-54.

Cesaretti, Paolo. Teodora, tłum. Bogumiła Bielańska, (Warszawa : Świat Książki, 2003).

Diringer, David. The Book before Printing: Ancient, Medieval and Oriental, (New York : Dover Publications, 1982).

Dzielska, Maria. Hypatia z Aleksandrii, wyd. 2, (Kraków : Universitas, 2006).

Garland, Lynda. Byzantine Empresses: Women and Power in Byzantium, $A D$ 527-1204, (London-New York : Routledge, 1999).

Gouma-Peterson, Thalia (red.), Anna Komnene and Her Times, (New York : Garland Publishing, Inc., 2000).

Grieser, Heike. Olympias, w: Reallexikon für Antike und Christentum, t. 26, (Stuttgart : Anton Hiersemann Verlag, 2015), 125-131.

Gutzwiller, Kathryn J. “Anyte's Epigram Book”, Syllecta Classica, t. 4, 1993, 71-89. 
Harries, Jill. Law and Empire in Late Antiquity, (Cambridge : Cambridge University Press, 1999).

Harris, William V. Ancient Literacy, (Cambrdige, Mass.-London : Harvard University Press, 1989).

Hefele, Charles J. Leclercq, Henri. Histoire des conciles d'après les documents originaux, (Paris : Letouzey et Ané, Éditeurs, 1907-1952).

Herrin, Judith. Women in Purple: Rulers of Medieval Byzantium, (London : Phoenix Press, 2002).

Hill, Barbara. Imperial Women in Byzantium 1025-1204. Power, Patronage and Ideology, (New York : Routledge, 1999).

Hillner, Julia. "Empresses, Queens, and Letters: Finding a 'Female Voice' in Late Antiquity?", Gender \& History, vol. 31.2, 2019, 353-382.

Holmes, Catherine. Waring, Judith (red.), Literacy, Education and Manuscript Transmission in Byzantium and Beyond, (Leiden-Boston-Cologne : Brill, 2002).

Holum, Kenneth G. Theodosian Empresses. Women and Imperial Dominion in Late Antiquity, (Berkeley-Los Angeles : University of California Press, 1982).

Ilski, Kazimierz. „Eudokia Athenais - eine Dichterin in der Welt der Politik“, $\mathrm{w}$ : Motivi e forme della poesia cristiana antica tra scrittura e tradizione classica. XXXVI Incontro di studiosi dell'antichità cristiana, Roma, 3-5 maggio 2007, (Roma : Institutum Patristicum Augustinianum, 2008), 443-451.

James, Liz. Empresses and Power in Early Byzantium, (London-New York : Leicester University Press, 2001).

James, Liz. "The Role of Women", w: Elizabeth Jeffreys, John Haldon, Robin Cormack (red.), The Oxford Handbook of Byzantine Studies, (Oxford : Oxford University Press, 2008), 643-651.

James, Liz. Women, men and eunuchs: gender in Byzantium, (London-New York : Routledge, 1997).

Kompa, Andrzej. „Kobieta rzymska, kobieta bizantyńska - co studia klasyczne moga zaoferować dzisiejszym gender studies?”, w: Bożena Czwojdrak, Agata A. Kluczek (red.), Kobieta i władza w czasach dawnych, (Katowice : Wydawnictwo Uniwersytetu Śląskiego, 2015), 49-68. 
Kouli, Maria. "Life of St. Mary of Egypt", w: Alice-Mary Talbot (red.), Holy Women of Byzantium. Ten Saints' Lives in English Translation, (Washington D.C. : Dumbarton Oaks Research Library and Collection, 1996), 65-93.

Lardinois, Andre. McClure, Laura (red.), Making Silence Speak. Women's Voices in Greek Literature and Society, (Princeton : Princeton University Press, 2018).

Leszka, Małgorzata B. Leszka, Mirosław J. Bazylisa. Świat bizantyńskich cesarzowych. IV-XV wiek, (Łódź : Wydawnictwo Uniwersytetu Łódzkiego, 2017).

Musiał, Danuta. „Kobieta i mężczyzna w świecie antycznym: uwagi o starych sporach i nowych oczekiwaniach", Klio. Czasopismo poświęcone dziejom Polski i powszechnym, t. 26, 2013, 5-16.

Neville, Leonora. Anna Komnene: the life and work of a medieval historian, (New York : Oxford University Press, 2016).

Patlagean, Évelyne. "Discours écrit, discours parlé. Niveaux de culture à Byzance aux VII -XI' siècles”, Annales ESC, t. 34, 1979, 264-278.

Patlagean, Évelyne. Pauvreté économique et pauvreté sociale à Byzance: $4^{e}-7^{e}$ siècles, (Paris : Mouton, 1977).

Powell, Jim. The Poetry of Sappho, (Oxford : Oxford University Press, 2007). Robbins, Emmet. „Telesilla”, w: Der Neue Pauly, t. 12/1, (Stuttgart : Metzler Verlag, 2002), 96.

Rudakow, Aleksandr. Очерки византийской культуры по данным греческой агиографии, (Moskwa : b.m.w., 1917).

Świderkówna, Anna (red.), Słownik pisarzy antycznych, (Warszawa : Wydawnictwo Wiedza Powszechna, 2001).

Talbot, Alice-Mary (ed.), Holy Women of Byzantium. Ten Saints' Lives in English Translation, (Washington D.C. : Dumbarton Oaks Research Library and Collection, 1996).

Tanaseanu-Döbler, Ilinca. "Sosipatra - Role Models for "Divine" Women in Late Antiquity”, w: Maria Dzielska, Kamilla Twardowska (red.), Divine Men and Women in the History and Society of Late Hellenism, (Kraków : Wydawnictwo Uniwersytetu Jagiellońskiego, 2013), 123-147.

Twardowska, Kamilla. Cesarzowe bizantyjskie 2 poł. Vw. Kobiety a władza, (Kraków : Towarzystwo Wydawnicze „Historia Iagellonica”, 2006). 
Twardowska, Kamilla. "Religious Foundations of Empress Athenais Eudocia in Palestine", w: Kamilla Twardowska, Maciej Salamon, Sławomir Sprawski, Michał Stachura, Stanisław Turlej (red.), Within the Circle of Ancient Ideas and Virtues. Studies in Honour of Professor Maria Dzielska, (Kraków : Towarzystwo Wydawnicze „Historia Iagellonica”, 2014), 307-317.

Winniczuk, Lidia. Twórczość poetek greckich, (Warszawa : Państwowe Wydawnictwo Naukowe, 1956).

Wipszycka, Ewa. Drugi dar Nilu czyli o mnichach i klasztorach w późnoantycznym Egipcie, (Kraków : Wydawnictwo Tyniec, 2014).

Wipszycka, Ewa. Kościół w świecie późnego antyku, (Warszawa : Państwowy Instytut Wydawniczy, 1994).

Wipszycka, Ewa. „Z problematyki badań nad zasięgiem znajomości pisma w starożytności", Przegląd Historyczny, t. 74, 1983, 1-27.

Wipszycka, Ewa. „Źródła normatywne świeckie”, w: Ewa Wipszycka (red.), Vademecum historyka starożytnej Grecji i Rzymu, t. 3, Źródłoznawstwo czasów późnego antyku, (Warszawa: Wydawnictwo Naukowe PWN, 1999), 585-617.

Wipszycka, Ewa. Wiśniewski, Robert. „Hagiografia późnoantyczna”, w: Ewa Wipszycka (red.), Vademecum historyka starożytnej Grecji i Rzymu, t. 3, Źródłoznawstwo czasów późnego antyku, (Warszawa : Wydawnictwo Naukowe PWN, 1999), 221-333. 